\title{
Evaluation of Diethyl Ether (DEE) as a Renewable Transport Fuel in Sudan
}

\author{
Mohamed Yagoub Alkhalil Karar, Hamid M. Mustafa, and Eltjani EL. Hago
}

\begin{abstract}
This study was conducted to investigate physicochemical properties, copper corrosion test and test the diesel engine performance of diethyl ether diesel blend fuel. With aid of distillation characteristic, the blends percentage were selected as DEE5\%, DEE10, DEE15 and DEE20\%. Stabinger Viscometer apparatus was used to determine the Kinematic viscosities, Digital Density Analyzer was used to determine the densities. ASTM D 4737 - 03 Test Method are used to determined calculated Cetane index. Copper strip corrosion device was used to determine corrosiveness of copper from diesel and DEE diesel blends. A single cylinder, four stroke diesel engines, mounted on a moving frame was used to conduct the engine test. From the study result we found that that blends physicochemical properties improved with diethyl ether ratio increased in the blends. While Cetane Index increased with diethyl ether ratio increased. At the higher load, the best result of Break thermal efficiency found at DEE10\%, where at the low load, the best mechanical efficiency found at DEE5\%, DEE15\% and DEE20 and at the higher load, the best mechanical efficiency found at DEE20\%, on other hand at the low load, the best specific fuel consumption found at DEE15\%, While at the higher load the best specific fuel consumption found at DEE10\%. Due to availability of diethyl ether in Sudan, diethyl ether can be used up to $10 \%$ in diesel blend with no further changed in diesel engine design, and this can be contributed to overcome the diesel fuel crisis in Sudan, but further information and studies are needed for diethyl ether transportation and blending facilities, beside study the effect the addition of diethyl ether on diesel price.
\end{abstract}

Index Terms - Diesel engine; Oxygenates; Synthetic fuel; Diethyl ether; Optimum; Distillation; Blend; Transport; Renewable.

\section{INTRODUCTION}

Sudan is considered has a potential to produce diethyl ether, in 2013 local government company launched a diethyl ether production plant based on Ethanol as feed stock under the catalysis of sulfuric acid. Ethanol supplied from local sources Sugar Company, that is owned an ethanol plant with the capacity to produce 65 million litters annually.[1] On the other hand, diethyl ether has promise best fuel properties, offer important environmental benefits as oxygenated fuel led to eliminate Green House gases generation form traditional fuels. Different studies talk about using diethyl ether as blend fuel with different percentage, but there is a lack of comprehensive evaluation considering higher volatility of diethyl ether with flash point about $\left(-45^{\circ} \mathrm{C}\right)$ and the effect of addition diethyl ether on diesel corrosivity. This encourages the author to conducted comprehensive study of diethyl ether diesel blend, covering the distillation characteristics, effect of blended fuel on metal corrosion rate, so as to select appropriate blends percentage form the safety point of view, and satisfy the hot weather condition in Sudan, where the temperature was rise up to more than $\left(45^{\circ} \mathrm{C}\right)$ in the summer season.

\section{A. Principle for Manufacturing Diethyl Ether}

Two alcohol molecules can form into one ether molecule and one water molecule under the action of catalyst the reaction formula is shown as follows:

$$
2 \mathrm{CH}_{3} \mathrm{CH}_{2} \mathrm{OH} \stackrel{\text { catalyse }}{\longrightarrow} \mathrm{CH}_{3} \mathrm{CH}_{2} \mathrm{OCH}_{2} \mathrm{CH}_{3}+\mathrm{H}_{2} \mathrm{O}
$$

In fact, the reaction, making ether from alcohol under the catalysis of sulfuric acid, is divided into two steps. First alcohol reacts with sulfuric acid and forms into ester which is called ethyl sulfuric acid.

$$
\mathrm{CH}_{3} \mathrm{CH}_{2} \mathrm{OH}+\mathrm{SO}_{2}(\mathrm{OH})_{2} \longrightarrow \mathrm{H}_{2} \mathrm{O}+\mathrm{CH}_{3} \mathrm{CH}_{2} \mathrm{OSO} \mathrm{O}_{2} \mathrm{OH}
$$

This resultant is stable at middle temperature, when heating ethyl sulfuric acid and the excessive alcohol up to (20 $\sim 140{ }^{\circ} \mathrm{C}$, ethyl sulfuric acid will be resolved into ether and sulfuric acid.

$$
\begin{aligned}
& \mathrm{CH}_{3} \mathrm{CH}_{2} \mathrm{OSO}_{2} \mathrm{OH}+\mathrm{CH}_{3} \mathrm{CH}_{2} \mathrm{OH} \stackrel{120 \sim 140^{\circ} \mathrm{C}}{\longrightarrow} \\
& \mathrm{SO}_{2}(\mathrm{OH})_{2}+\mathrm{CH}_{3} \mathrm{CH}_{2} \mathrm{OCH}_{2} \mathrm{CH}_{3}
\end{aligned}
$$

If this reaction is done at $120 \sim 140{ }^{\circ} \mathrm{C}$ and an alcohol is added into the reactor continuously, the producing ether and water will be distilled continuously. This reaction can keep going without end in theory, but because acid is diluted by water and some part of them is reduced to sulfurous acid, the etherification will stop at the end. [3], [4].

\footnotetext{
Published on January 3, 2021.

Mohamed Yagoub Alkhalil Karar, College of Graduate Studies \& Scientific Research, University of Karary, Sudan.

(e-mail: m.karar1972@gmail.com)

Hamid M. Mustafa, Department of Chemical Engineering, University of

Science \& Technology, Sudan.

(e-mail: hamidmustafa5@gmail.com)

Eltjani EL. Hago, Department of Chemical Engineering, Karary

University, Sudan.

(e-mail: eltjanihago@gmail.com).
} 


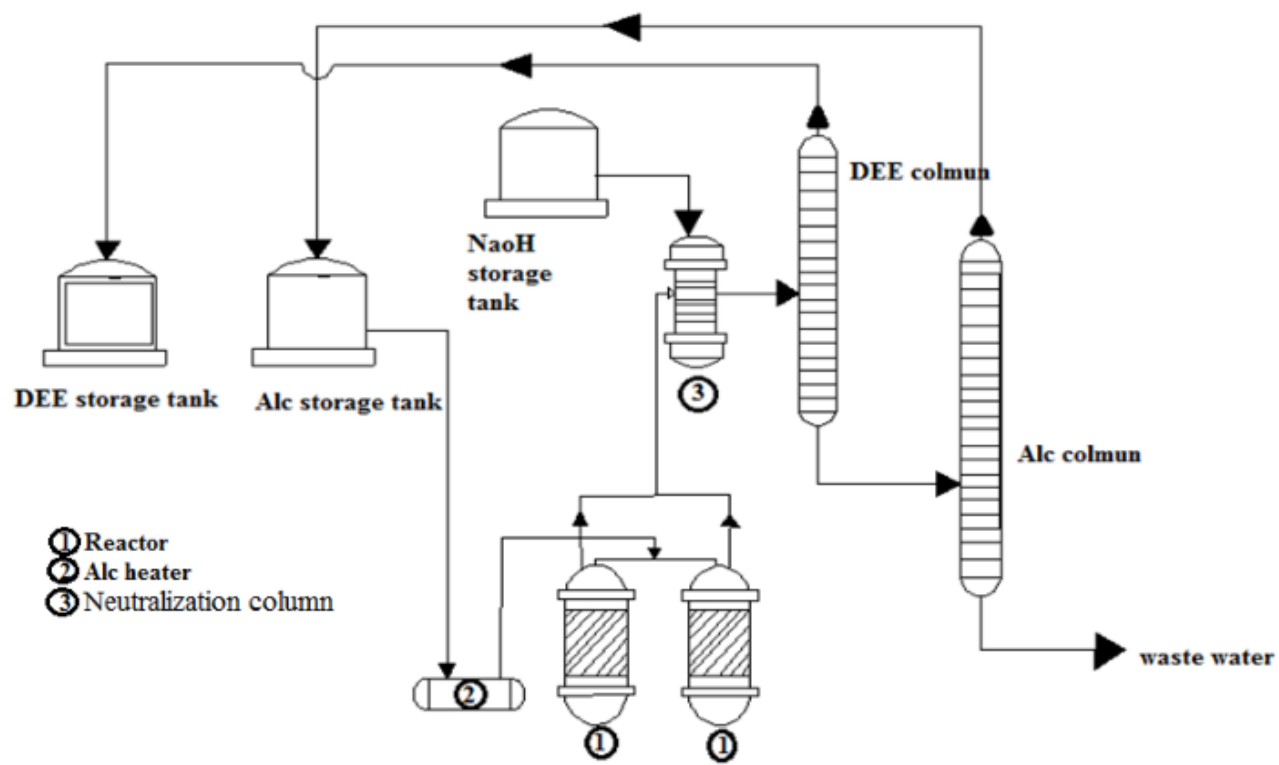

Fig. 1. Ether manufacturing flow diagram typical Sudan plant.

TABLE I: PHYSICOCHEMICAL PROPERTIES OF DIESEL FUEL AND DIETHYL ETHER. TYPICALLY PRODUCED IN SUDAN

\begin{tabular}{|c|c|c|c|}
\hline $\mathrm{NO}$ & Property & Diesel & Diethyl ether \\
\hline 1 & Molecular Weight & $181 \mathrm{~g} / \mathrm{mol}$ & $74.1216 \mathrm{~g} / \mathrm{mol}$ \\
\hline 2 & Molecular Formula & $\mathrm{C}_{13} \mathrm{H}_{24}$ & $\mathrm{C}_{4} \mathrm{H}_{10} \mathrm{O}$ \\
\hline 3 & Appearance & Light yellow liquid & Colorless liquid \\
\hline 4 & Density & $850 \mathrm{~kg} / \mathrm{m}^{3}$ & $719 \mathrm{~kg} / \mathrm{m}^{3}$ \\
\hline 5 & Boiling point & $266^{\circ} \mathrm{C}$ & $34.6^{\circ} \mathrm{C}$ \\
\hline 6 & Flash point & $81^{\circ} \mathrm{C}$ & $-45^{\circ} \mathrm{C}$ \\
\hline 7 & Volatility & Volatile & Highly volatile \\
\hline 8 & $\begin{array}{c}\text { Kinematic viscosity } \\
\text { @ 40oC }\end{array}$ & $3.05 \mathrm{cSt}$ & $0.223 \mathrm{cSt}$ \\
\hline 9 & $\begin{array}{c}\text { Auto-ignition } \\
\text { temperature }\end{array}$ & $3160^{\circ} \mathrm{C}$ & $160^{\circ} \mathrm{C}$ \\
\hline 10 & Heating value & $43000 \mathrm{~kJ} / \mathrm{kg}$ & $33892 \mathrm{~kJ} / \mathrm{kg}$ \\
\hline 11 & $\begin{array}{c}\text { Surface tension @ } \\
20^{\circ} \mathrm{C}\end{array}$ & $0.023 \mathrm{~N} / \mathrm{m}$ & $376 \mathrm{~N} / \mathrm{m}$ \\
\hline 12 & Flammability & Flammable & Flammable \\
\hline 13 & Cetane number & $(45-55)$ & $(85-89)$ \\
\hline 14 & $\begin{array}{c}\text { Carbon content (\% } \\
\text { weight) }\end{array}$ & $(84-87)$ & 64.86 \\
\hline 15 & $\begin{array}{c}\text { Hydrogen content (\% } \\
\text { weight) }\end{array}$ & $33-16$ & 13.5 \\
\hline 16 & $\begin{array}{l}\text { Oxygen content (\% } \\
\text { weight) }\end{array}$ & 0 & 21 \\
\hline 17 & $\begin{array}{l}\text { Stoichiometric air- } \\
\text { fuel ratio }\end{array}$ & 15 & 11.1 \\
\hline 18 & $\begin{array}{c}\text { Latent heat of } \\
\text { vaporization }\end{array}$ & $250 \mathrm{~kJ} / \mathrm{kg}$ & $376 \mathrm{~kJ} / \mathrm{kg}$ \\
\hline
\end{tabular}

\section{B. Statement of the Problem}

\section{1) Overview}

Sudan largely dependent on crude oil for producing transport fuel but it lost 350,000 barrels per day after the cessation of the South Sudan and this resulted in a lack of transport fuel. On the other hand, Sudan has a Global commitment for reducing Green House emissions [5]. According to above mentioned statement there is need of arrangements to introduce renewable sources of fuel in Sudan.

\section{2) Diethyl Ether Diesel Blend Preparation}

The volatility behaviour of a fuel has a direct impact on the performance of diesel engines, if the volatility is high, it can lead to the fuel explosion in the combustion chamber and in the line, and since the diethyl ether is more volatile than diesel, thus the one of the very important steps of diethyl ether diesel blends preparation is to identify the safer diethyl ether diesel blends percentage. To overcome this problem, Batch Distillation test was used to determine the volatility of diesel and blends that is gives accurate indicator about diesel and blends volatility [6].

\section{Scope of Work}

To achieve the study, target the project was going focus on the below objectives:

1. Conducting blends distillation test to determine the volatility of diesel and blends and identify appropriate blends percentage

2. Investigate, physicochemical properties of diethyl ether and diesel blends fuel.

3. Investigate the effect of DEE diesel blend on metal corrosion rate and compare them with pure diesel.

4. Study the effect of DEE diesel blend on diesel engine performance.

\section{MATERIALS AND METHODS}

Blend fuel distillation characteristic and physicochemical properties, beside copper corrosion test was carried out in Central Laboratory for Khartoum Refinery Company (KRC) using ASTM procedure. While diesel engine test was carried out at University of Karary.

\section{A. Lab Tests Apparatus \& ASTM Methods}

Batch Distillation unit and (ASTM D 86-08a). Standard test method for distillation of petroleum products at atmospheric pressure were used to determine the volatility of diesel and blends. Stabinger Viscometer apparatus and (ASTM D 7042 - 04) were used to determine the Kinematic viscosities, Digital Density Analyzer and (D 4052-96 ASTM) Standard test method was used to determine the densities. (ASTM D 4737-03) Method are used to determined calculated Cetane index for blends. Copper strip corrosion device is pressure vessel constructed from stainless steel was used to determine corrosiveness to copper from diesel and DEE diesel blends, the vessel shall be 
capable to withstand a test pressure of $700 \mathrm{kPa}$ gu (100 psi). and (ASTM.D130-04) Standard test method for corrosiveness to Copper from Petroleum Products by Copper Strip Test was used to study the effect of diethyl on cooper corrosion rate. Lower Heating Value was calculated by Mixing rule applied by García et al. and Clements [7].

\section{AD86 5G2}

\section{DISTILLATION AUTOMATIC ANALYZER}

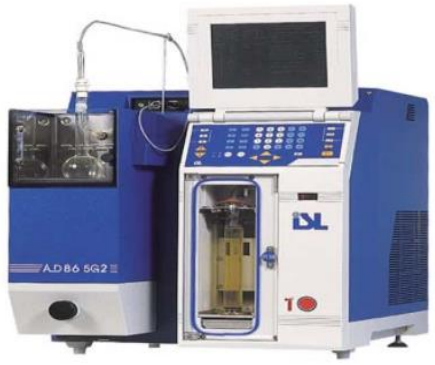

Fig. 2. Batch Distillation Analyzer.

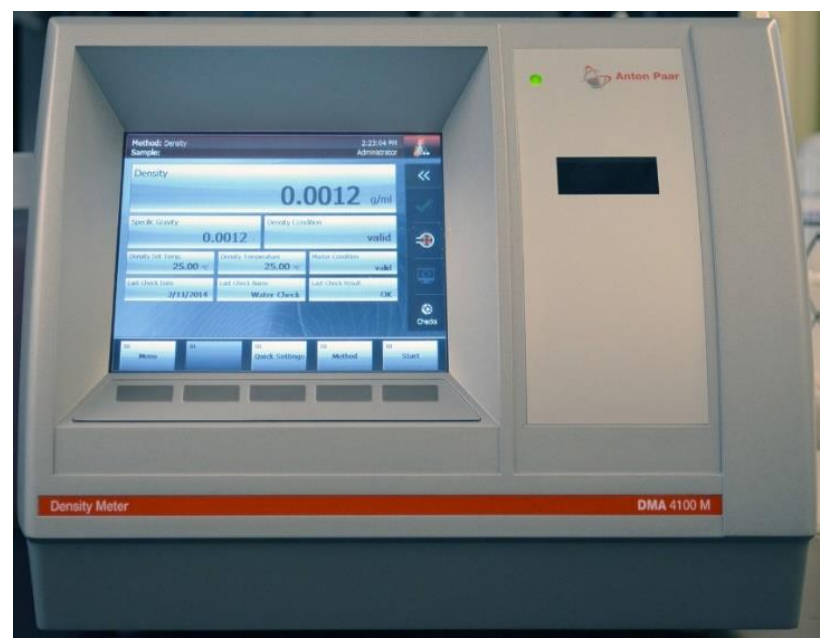

Fig. 3. Density Meter.

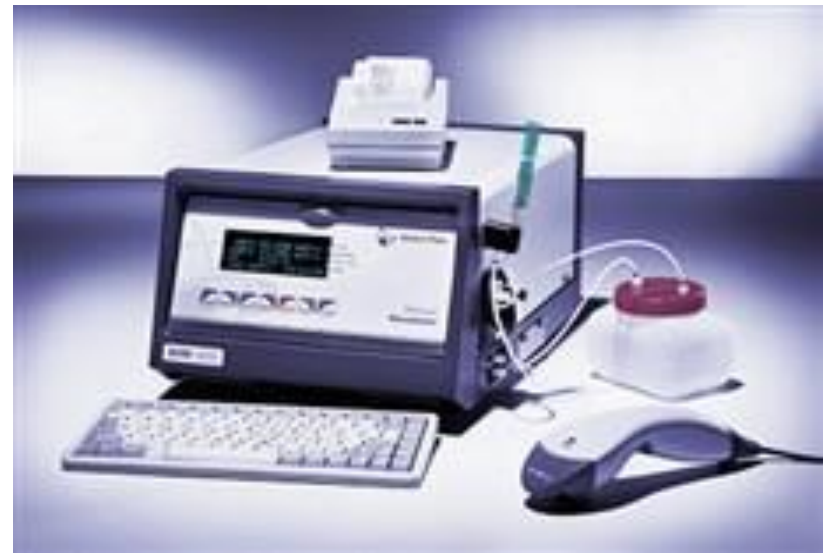

Fig. 4. Viscometer.

\section{B. Test Engine Rig}

A single cylinder, four stroke diesel engines compression engine, mounted on a moving frame was used for the conducted the engine test. The general specifications of the engine were described in Table II.

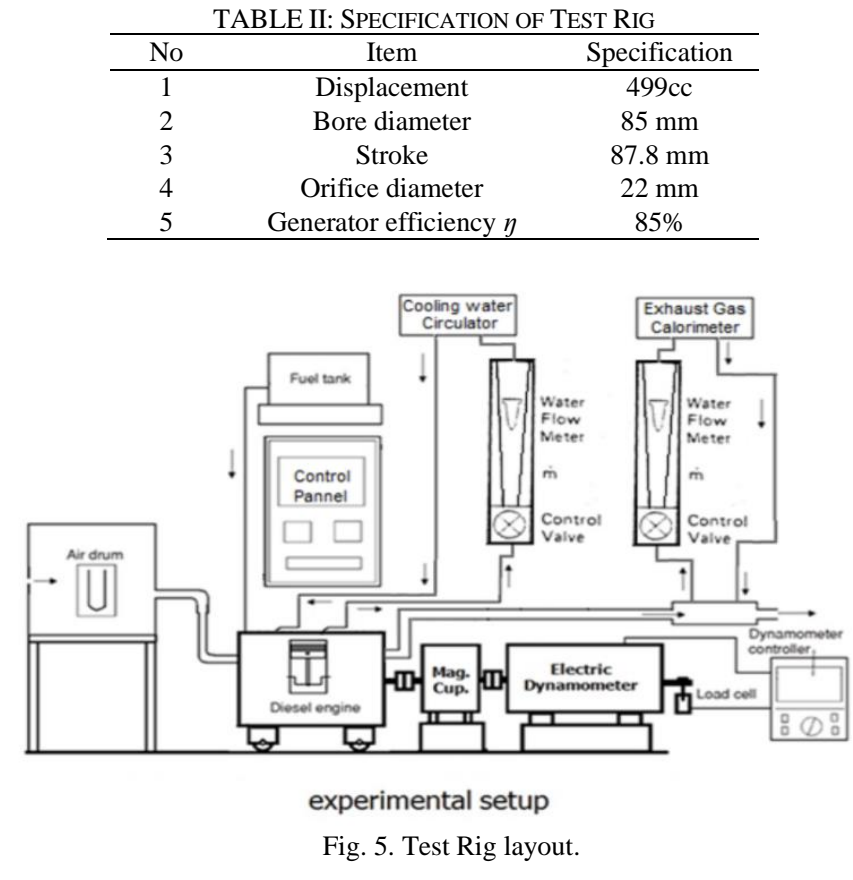

\section{RESULTS AND DISCUSSIONS}

\section{A. Results}

The results of test of distillation, density, Kinematic viscosity, heating value, Cetane index, Copper Corrosion Test, Brake thermal efficiency, Mechanical efficiency, Specific fuel consumption were shows in Fig.6-14. Respectively.

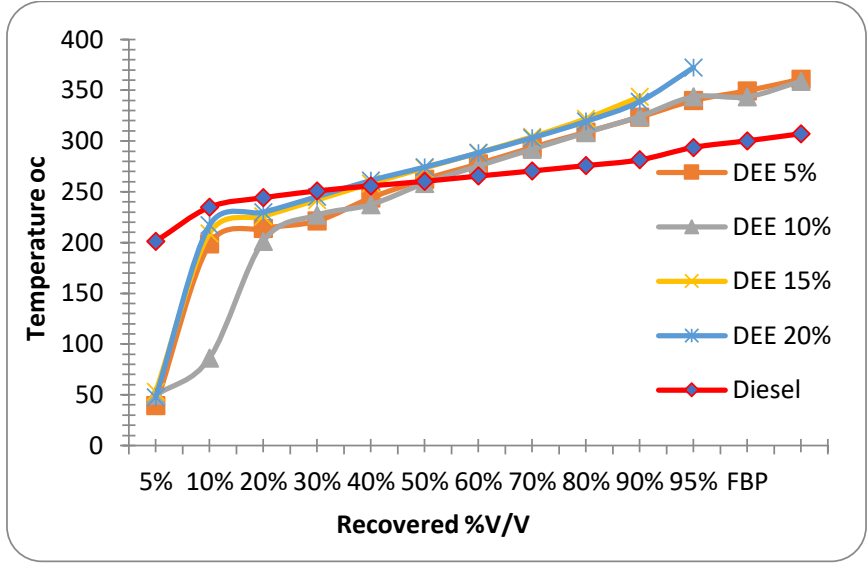

Fig. 6. Distillation Curves for Diethyl Ether Diesel Blends.

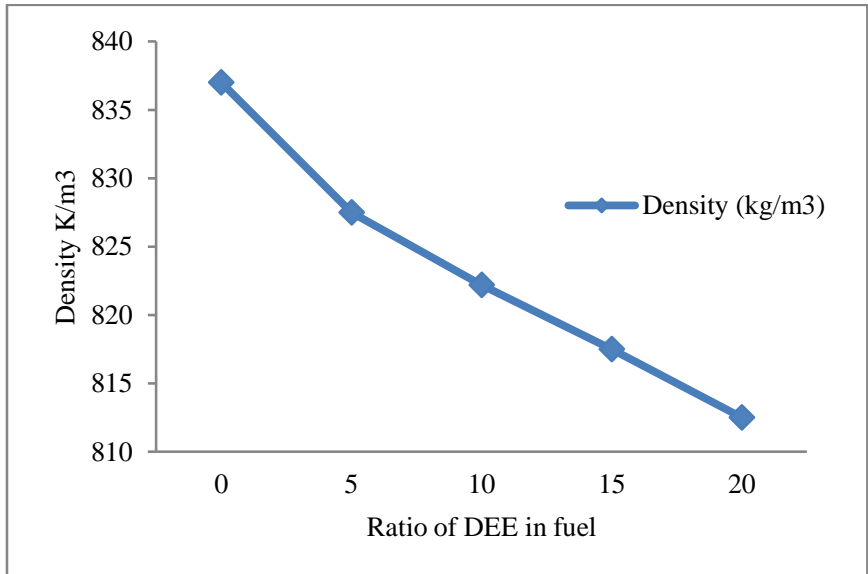

Fig. 7 Density of Diethyl Ether Diesel Blends. 


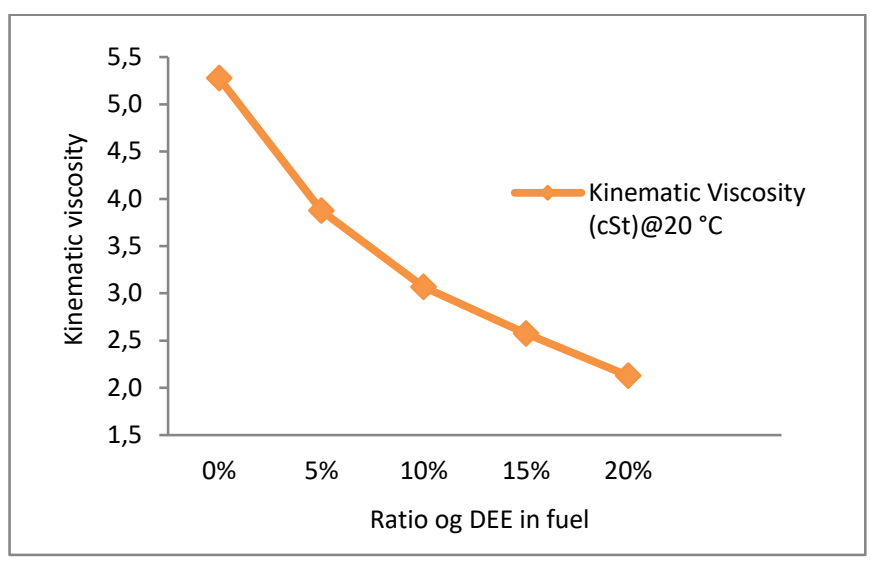

Fig. 8. Kinematic viscosity of Diethyl Ether Diesel Blends.

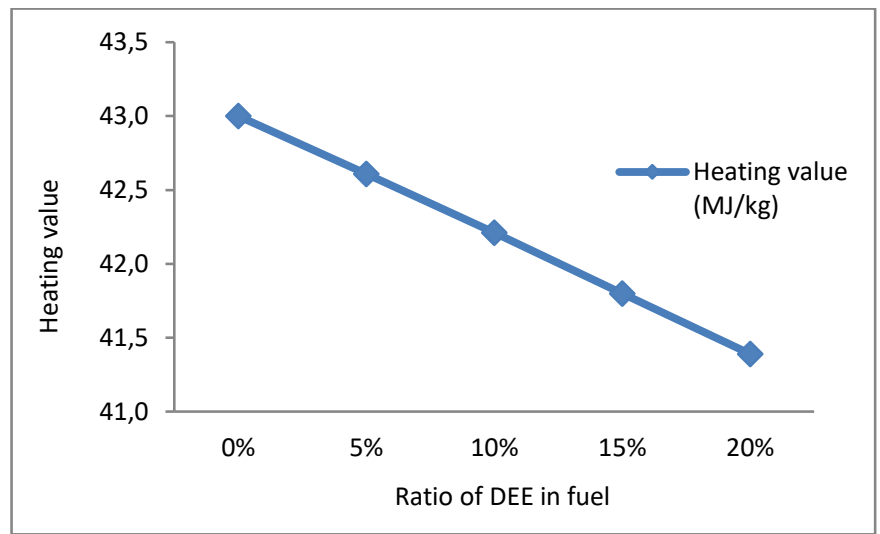

Fig. 9. Heating Value of Diethyl Ether Diesel Blends.

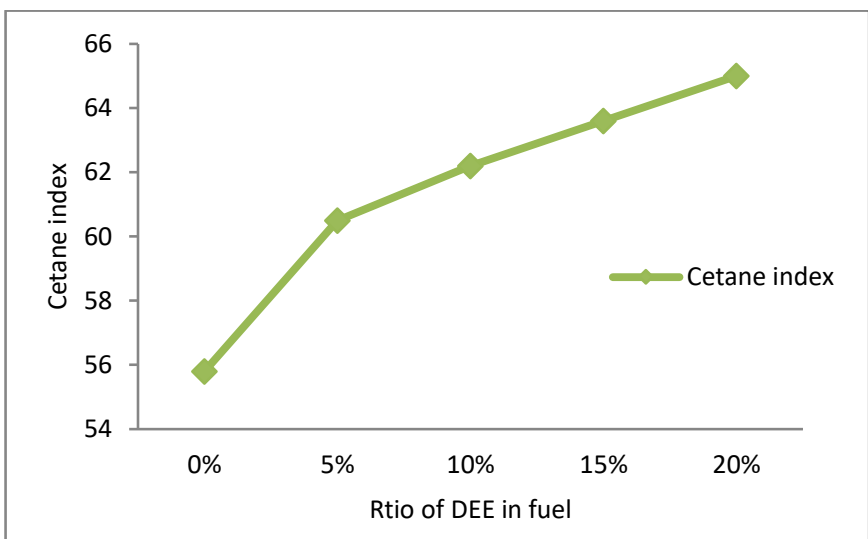

Fig. 10. Cetane Index of Diethyl Ether Diesel Blends.

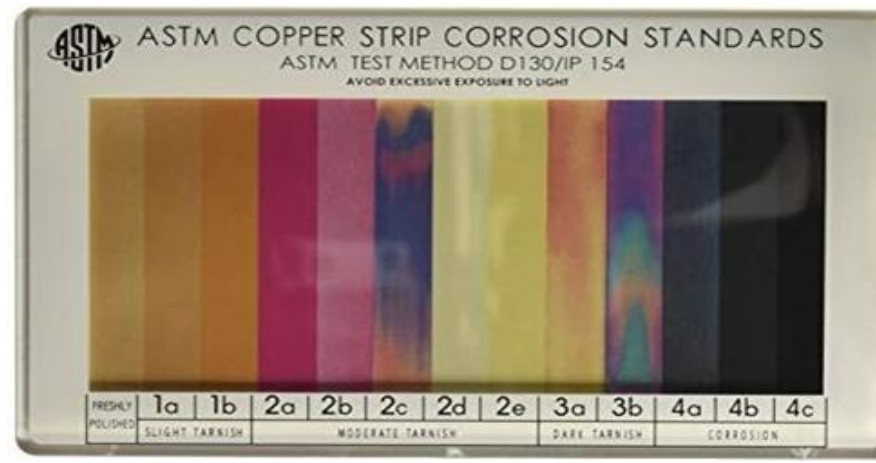

Fig. 11. Copper strip corrosion standard result of Diethyl Ether Diesel Blends.

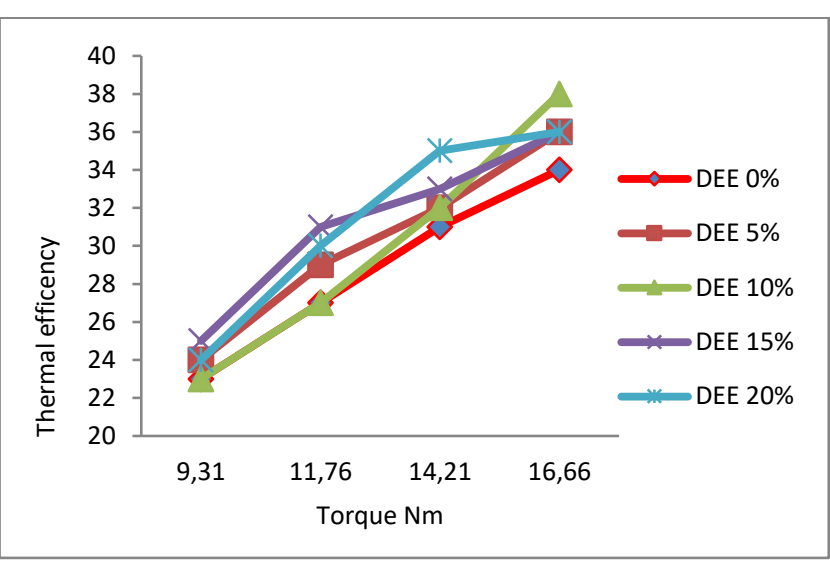

Fig. 12. Break Thermal Efficiency V.S Load for Diethyl Ether Diesel Blends.

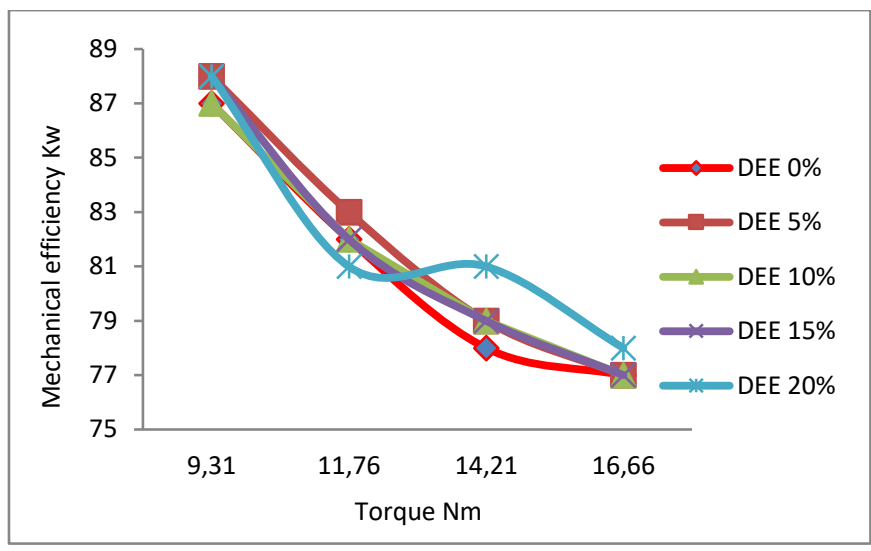

Fig. 13. Mechanical efficiency V.S Load for Diethyl Ether Diesel Blends.

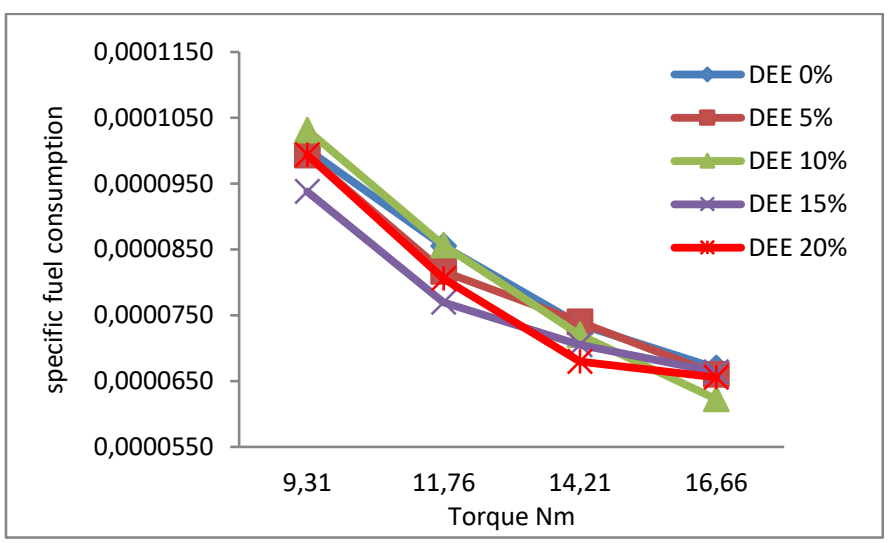

Fig.14. Specific Fuel Consumption V.S Load for Diethyl Ether Diesel Blends.

\section{B. Discussions}

Fig. 6 shows that the initial boiling point IBP for DEE5\% started at $39.5{ }^{\circ} \mathrm{C}$ and recovered temperature gradually increase up to $300.2{ }^{\circ} \mathrm{C}$ at $\mathrm{R} 95$ and the sample totally recovered at $\left(307.2{ }^{\circ} \mathrm{C}\right)$. For DEE10\% the initial boiling point IBP started at $49.5{ }^{\circ} \mathrm{C}$ and recovered temperature gradually increase up to $\mathrm{R} 95$ and the sample totally recovered at $360.9^{\circ} \mathrm{C}$. For DEE15\% the initial boiling point IBP started at $53 .{ }^{\circ} \mathrm{C}$ and recovered temperature gradually increase up to R70 and the sample totally recovered at R80. For DEE $20 \%$ the initial boiling point IBP started at $47.7^{\circ} \mathrm{C}$ and recovered temperature gradually increase up to R80 and the sample totally recovered at $\mathrm{R} 90{ }^{\circ} \mathrm{C}$.

Fig. 7 shows that the blend densities, were found to be $2.7 \%, 3.22 .8 \%, 3.8 \%$ and $4.4 \%$ less than pure diesel for 
DEE5\%, DEE15\%, DEE15\% and DEE20\% blends respectively and this due to diethyl ether has a less density than the pure diesel.

Fig. 8 shows that kinematic viscosity of blends they were found to be $26.5 \%, 41.8 \%, 51.2 \%$ and $59.6 \%$ less viscous than pure diesel fuel $\left(5.275\right.$ (cSt)@20 $\left.{ }^{\circ} \mathrm{C}\right)$ for DEE5\%, DEE15\%, DEE15\% and DEE20\% blends respectively and this due to diethyl ether has a low Kinematic viscosity than pure diesel.

Fig. 9 shows that the heating value of blends decreased by $0.91 \%, 1.8 \%, 2.8 \%$, and $3.7 \%$ for DEE5\%, DEE $10 \%$, DEE15\% and DEE20\%, respectively, compared to pure diesel, and this due to diethyl ether has a lower heating value than pure diesel.

Fig. 10 shows that blends Cetane index continuously increased by $8.4 \%, 11.5 \%, 14 \%$, and $16.5 \%$ for DEE $5 \%$, DEE $10 \%$, DEE15\%, and DEE20\%, blends respectively this due to higher Cetane index of pure ether which was (85).

Fig 11 shows that there is no colour change was observed to cooper strip under test for all blends that is reading 1a, the result there is no effect observed on diesel corrosivity when DEE ratio increases in the blends.

Fig. 12 indicate the Brake thermal efficiency vs. load. The BTE was proportional increase with the load increases for each blend. This because diethyl ether has an Oxygen content which enhance the diesel combustion, but at the higher load the best Break thermal efficiency found at DEE10\%.

Fig. 13 Indicate the mechanical efficiency vs. load, the mechanical efficiency was inversely proportional to the load increase for all blends, at the low load the optimum value found at DEE5\%, DEE15\% and DEE20\%, at the higher load the optimum value found at DEE20\%.

Fig. 14 indicate the specific fuel consumption vs. load, at the low load the optimum value of specific fuel consumption found at DEE15\%, while at the higher load the optimum specific fuel consumption value found at DEE10\%. In generally the specific fuel consumption was little improved by increase diethyl ether ratio in the blend and this because it has an Oxygen atom which enhance the diesel fuel combustion.

\section{CONCLUSIONS AND RECOMMENDATIONS}

\section{A. Conclusion}

Addition of diethyl ether to pure diesel up to $20 \%$ improve the physicochemical properties of the diesel such as density and kinematic viscosity and slightly lowering the heating value. While Cetane index increased with the increased diethyl ether ratio increased in the blends, and there was no effect on diesel corrosivity to the metal have been observed. On the other hand, improvement of the diesel engine performance such as Break thermal efficiency, mechanical efficiency, and specific fuel consumption have been observed, and best values found at DEE10\% and DEE15\%.

\section{B. Recommendations}

This study can be use as preliminary guidelines and recommendation for deployment and implementation of diethyl ether as alternative transport fuel in Sudan, and the author recommended that:

1. Diethyl ether can be used up to $10 \%$ in diesel blend with no further changed in diesel engine design

2. Utilized the existing diethyl ether plant infrastructure, for storage and suppling diethyl ether since the material used for sample blend preparation, was supplied from this plant.

3 . Khartoum refinery company is a main source of diesel in Sudan, is nearby diethyl ether plant, about only four Kilometer away, and this facilitate the transportation of diethyl ethe from production area to refinery area so that the blending pool can be stablish there.

4. further information and studies are needed for diethyl ethe transportation and blending facilities.

5. There is need for study the effect of addition of diethyl ethe in diesel price.

\section{LIST OF ABBREVIATIONS}

\begin{tabular}{ll}
\hline DEE & Diethyl Ether \\
ASTM & American Society for Testing and Materials \\
KRC & Khartoum Refinery Company \\
DEE 5\% & Five present of diethyl ether diesel in Diesel \\
DEE10\% & Ten present of diethyl ether diesel in diesel \\
DEE15\% & Fifteen present of diethyl ether diesel in diesel \\
DEE20\% & Twenty present of diethyl ether diesel in diesel \\
IBP & Initial Boiling Point \\
R70 & Seventy Percent of Volume Recovered \\
R80 & Eighty Percent of Volume Recovered \\
R90 & Ninety Percent of Volume Recovered \\
R95 & Ninety Five Percent of Volume Recovered \\
HV & Heating Value \\
LHV & Lower Heating Value \\
B.T. E & Break Thermal Efficiency \\
SFC & Specific Fuel Consumption \\
\hline
\end{tabular}

\section{ACKNOWLEDGMENT}

First and I would like to ask Allah has mercy and forgiveness to Prof. Hamid. M. Mustafa, He passed away last month and more thank for ass Prof Eltjani. EL. Hago Without them I would not have achieved my goals for this thesis.

Secondly, I would like to thank my colleague Dr, Sarah Ibrahim, and my colleagues in Giad Industrial Group, Staff of central Laboratory of Khartoum Refinery Company and Department of Mechanical Engineering Karary University for their unlimited support to me to achieve my objective.

Last, but not least, I would like to thank my family members for their continuously support to achieve my goal.

\section{REFERENCES}

[1] Ministry of Information, "Sudan, the land of opportunities", July 2011, ISBN 233/2011.Page 4.

[2] Riza Alviany, Arifuddin Wahyudi, Ignatius Gunardi, Achmad Roesyadi, Firman Kurniawansyah, Danawati Hari Prajitno. "Diethyl Ether Production as a Substitute for Gasoline", MATEC Web of Conferences, 2018.

[3] Widayat, Achmad Roesyadi, Muhammad Rachimoellah "Diethyl Ether Production Process with Various Catalyst Type" Internat. Journal. of Sciences. and Engineering., Vol. 4(1):6-10, January 2013, Widayat et al. 
[4] James G. Speight, Chemical and process design hand book, 2002 The McGraw-Hill Companies, Inc, Part 2.211, pp.269.

[5] Intergovernmental Panel on Climate Change IPCC 1997. IPCC Guidelines for National Greenhouse Gas Inventories. Reference Manual (Revised). Vols1, 2nd 3.J.T. Houghton et al., IPCC/OECD/IEA, Paris, France.

[6] Ma Mercedes del Coro Fernández-Feal, Luis R. Sánchez-Fernández and, Blanca Sánchez-Fernández, (2017), "Distillation: Basic Test in Quality Control of Automotive Fuels", [Online]. pp. 81. Available: http://dx.doi.org/10.5772/67140.

[7] Cherng-Yuan Lin, "Effects of Biodiesel Blend on Marine Fuel Characteristics for Marine Vessels", Energies, vol.6, pp 4945-4955, 24 September 2013.

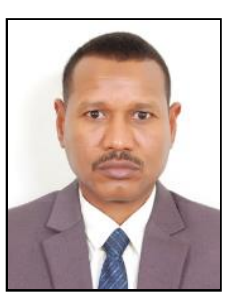

Mohamed Yagoub Alkhalil Karar, BSc. of Chemical Engineering awarded from Red Sea University October 1999, Port Sudan-Sudan, Master's degree of Cleaner Production 2015, Sudan Academy of Science Council of Engineering and Industrial Technology, Khartoum Sudan. Chemical Engineering Ph.D. Programme, Karary University, Sudan.

Dr. Karar was NEBOSH, IOSH and OSHA Certified, and he is member of Sudanese Engineering Council \& Saudi Council of Engineers.

He has more than 18 Years of experience in the field of Chemical and Petrochemical Industry, the current position of Dr, Karar as production consultant. Advise on all aspects of the plant operation, including production, maintenance, and quality control. Other responsibilities include plant optimization to ensure maximum production, quantity and quality and oversees all plant operations and production and providing leadership to managers in the different departments, Production, Maintenance, Lab, and others. 